\title{
Approaches to Writing in EFL/ESL Context: Balancing Product and Process in Writing Class at Tertiary Level
}

\author{
Md. Kamrul Hasan \& Mohd. Moniruzzaman Akhand
}

\begin{abstract}
This article presents the findings of an interventionist study designed to examine the effects of product and process approach to writing on learners' performance. Two ESL classes of United International University in Bangladesh participated in the study; initially one class was instructed to follow the method of writing of product approach, and the other received instruction on the process approach. Later a collaborative approach was adopted in both classes. Data were collected from the learners' performance in group works, discussions, observations of learners' strategy use, and from the end products. The findings indicate that the combination of product and process outperformed the presentation of the learners. There was corroborating evidence to support the view that the blend of both approaches tends to facilitate the learners to undertake a writing task to be developed. Finally, the advantages of using a product-process approach to gauging the effects of writing tasks are appraised.
\end{abstract}

Key words: Teaching English writing, the process approach, the product approach, incorporation of product process approach, guided brainstorming, top down approach

\section{Introduction}

The majority of students at most private universities in our country come from various streams, like, Science and Engineering, Bachelor of Business Administration (BBA), and most of them take English as any other course. So their exposure to English is not limited to six hours in a week. Moreover, it can be added here that the medium of instruction in all private universities is English. Along with other courses, they study and write English; however, their understanding of the texts and writing skill is not worth mention. From primary level to higher secondary level, most of the students in Bangladesh get exposure to English according to the syllabus of their institutions and those institutions follow Secondary School Certificate (S.S.C), Higher Secondary Certificate (H.S.C) or General Certificate of Education (G.C.E.) curriculum sanctioned by the respective boards.
We see that students face developing functional language skills, such as proper natural language in different social contexts and using language in creative ways. Thus, the majority of the students are more prone to memorizing and imitation. They fail to integrate critical thinking into their creative writings. The form of examination and evaluation only encourages students towards model-centred learning, where the students are guided by a model even though the opposite should be the case.

The conflict of product and process approach begins with the level of the students. In most of the English as a Second Language (ESL)/English as a Foreign Language (EFL) classes, we have mixed ability group that vary so widely that only one approach cannot be adopted. While in some classes product approach may prove fruitful, process approach may be useful for another. Some scholars 
also opt for genre approach. This paper argues that the bridging of the two might be a rightful claim to enhance the writing courses. Most scholars see these two concepts as complementary rather than opposites.

English has come to the stage of becoming the predominant language of international academic publication, regardless of the L1 of the authorsa fact attested by the importance attached to publication in specific English language media. This position of English resembles that of Latin in Europe's Middle Ages as an academic lingua franca, and continually strengthened by its increased use as a language of instruction at the tertiary level. In Bangladesh, there is a pressing need for composition class to help students develop their skills in using language by experiencing the whole writing process as well as the knowledge of the contexts in which creativity is encouraged and the purpose of the writing is made apparent. This paper analyzes the strengths and weaknesses of product and process approach in terms of writing and how the blend of product and process approach in ESL/EFL Classes showcases the development of writing. Furthermore, it is shown that the genre approach defined by the respective scholar is not the best alternative in terms of teaching English writing for students of private universities in Bangladesh. The researchers also try to show in this paper that the two approaches- product and process are complementary; both approaches help the other one to make a complete whole.

\section{Theoretical Background}

\section{Approaches to Writing: Product and Process}

The large numbers of recent studies concerned with the measurement of strategy training for L2/ FL learners have been product-oriented (Chen, 2007). Chen also mentions that these studies have quantitatively measured improvements in learners' test scores following the completion of a strategy training programme. Wenden (1987) mentions that the study of FL strategy training programme evaluation is concerned with the question of how the outcome of the learner training is measured. For effective writing in EFL/ ESL classroom, ELT practitioners suggest three approaches: product, process and genre. The best practice in any situation will depend on the type of student's competence level, the text type being studied, the curriculum and many other factors. In this connection, it is worth mentioning what Gardner and Johnson (1997) argue 'Writing is a fluid process created by writers as they work.... In actuality, the writing process is not a highly organized linear process, but rather a continual movement between different steps of the writing model'(p.36). In EFL/ESL classrooms, product and process approaches have dominated much of the teaching of writing over the last 20 years. In the last ten years, we have seen the growing importance of genre approaches in the EFL/ESL classrooms.

\section{Product Approach}

A product approach is "a traditional approach in which students are encouraged to mimic a model text, usually is presented and analyzed at an early stage" (Gabrielatos, 2002, p.5). For example, in a typical product approach-oriented classroom, students are supplied with a standard sample of text and they are expected to follow the standard to construct a new piece of writing.

Product Approach Model comprises of four stages (Steele, 2004)

Stage one: Students study model texts and then the features of the genre are highlighted. For example, if studying a formal letter, students' attention may be drawn to the importance of paragraphing and the language used to make formal requests. If a student reads a story, the focus may be on the techniques used to make the story interesting, and students focus on where and how the writer employs these techniques.

Stage two: This stage consists of controlled practice of the highlighted features, usually in isolation. So if students are studying a formal letter, they may be asked to practise the language used to make formal requests, for example, practising the 'I would be grateful if you would...' structure.

Stage three: This is the most important stage where the ideas are organized. Those who favour this approach believe that the organization of ideas is more important than the ideas themselves and as important as the control of language.

Stage four: This is the end product of the learning process. Students choose from the choice of 
comparable writing tasks. To show what they can be as fluent and competent users of the language, students individually use the skills, structures and vocabulary they have been taught to produce the product.

\section{Process Approach}

Kroll (2001) defines process approach as follows:

The "process approach" serves today as an umbrella term for many types of writing courses .... What the term captures is the fact that student writers engage in their writing tasks through a cyclical approach rather than a single-shot approach. They are not expected to produce and submit complete and polished responses to their writing assignments without going through stages of drafting and receiving feedback on their drafts, be it from peers and/or from the teacher, followed by revision of their evolving texts. (pp. 220-221).

Hence a process approach tends to focus more on varied classroom activities which promote the development of language use: brainstorming, group discussion and rewriting.

The Process Approach Model comprises of eight stages (Steele, 2004):

Stage one (Brainstorming): This is generating ideas by brainstorming and discussion. Students could be discussing the qualities needed to do a certain job. Brainstorming can be carried out as follows:

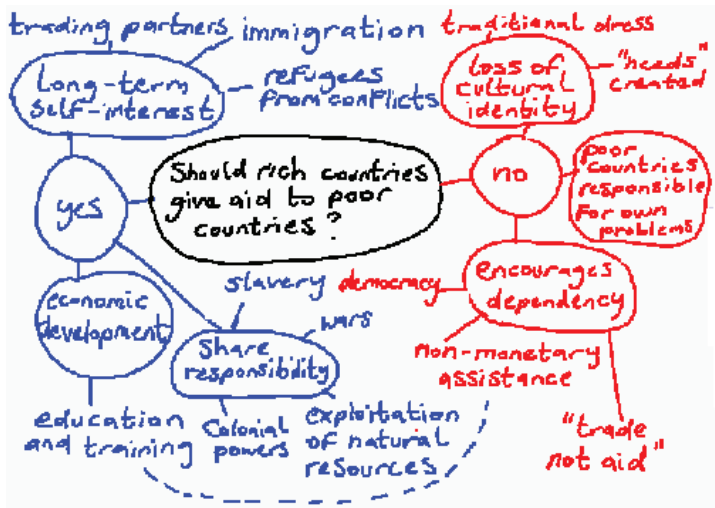

Figure 1: A sample of Brainstorming from a Student in Our EFL Classroom
The above brainstorming has been carried out on the topic 'Should rich countries give aid to poor countries?' in one of our EFL classrooms at United International University, Dhaka, Bangladesh. The left hand side presents the arguments for the topic while the right hand side presents the arguments against the topic.

Stage two (Planning/Structuring): Students exchange ideas into note form and judge quality and usefulness of the ideas.

Stage three (Mind mapping): Students organize ideas into a mind map, spidergram, or linear form. This stage helps to make the hierarchical relationship of ideas which helps students with the structure of their texts.

Stage four (Writing the first draft): Students write the first draft. This is done in the class frequently in pairs or groups.

Stage five (Peer feedback): Drafts are exchanged, so that students become the readers of each others work. By responding as readers students develop awareness of the fact that a writer is producing something to be read by someone else and thus they can improve their own drafts.

Stage six (Editing): Drafts are returned and improvements are made based upon peer feedback.

Stage seven (Final draft): A final draft is written.

Stage eight (Evaluation and teachers' feedback): Students' writings are evaluated and teachers provide a feedback on it.

The following diagram shows the cyclical nature and the interrelationship of the stages:

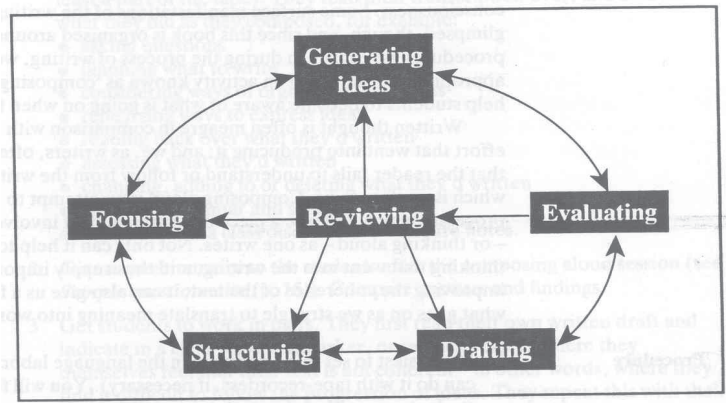

Figure 2: A model of writing (White and Arndt's (1991:43) diagram of process writing) 
White and Arndt's diagram (1991) offers teachers a framework which tries to capture the recursive, not linear, nature of writing.

Trupe (2001) mentions that to incorporate process instruction in our classes, we may remember the following points-

- $\quad$ Ask students to do a lot of writing, but don’t make every assignment count for a grade. Read some student texts as a "real" reader, responding to content without seeking to correct it.

- Give students some class time to start brainstorming on a writing topic after you've given an assignment. As little as 5 minutes can be effective.

- Encourage a variety of prewriting and planning strategies. Students sometimes need to do some writing before they know what their thesis will be. Some students work well from an outline, clustering, or creating a tree diagram. Others may benefit from generating a series of questions they have, or think their readers will have about their topic. Yet others benefit from visualizing a scenario in which they communicate the information (like a television news report or speech in a courtroom). Others can visualize by drawing scenes.

- Assign students to peer groups to give each other focused feedback on drafts. Prepare some guidelines for peer responders, so that they can look for specific textual features, and ask them to provide written feedback to the student authors. Peer group sessions can be held in class, face-to-face out of class, or in a computer environment (email, bulletin board, etc.).

- Encourage students to ask you questions about their writing, as they are working on papers.

- $\quad$ Practice formative assessment.

- If at all possible, schedule brief face-to-face conferences for discussion of student writing. Consider framing your comments in terms of questions, like, "What do you mean here?" or, "Can you tell me more about this?" rather than in evaluative statements.
- When students produce multiple drafts of an essay, you can hold them to very rigorous standards for the final product.

- Weight end-of-semester revisions and writing more heavily than early writing when you determine the final grade.

- Introduction of portfolio in case of final assessment.

\section{Differences}

Process driven approaches are similar to task based learning in that students are given considerable freedom within the task. They are not curved by the preventive teaching of lexical or grammatical items. However process approaches do not repudiate all interest in the product. The aim is to achieve the best product possible. What differentiate a process focused approach from the product centred one that the outcome of writing, the product, is not preconceived.

Table 1: Product and process writing: A comparison (Steele 2004 p. 1)

\begin{tabular}{|l|l|}
\hline \multicolumn{1}{|c|}{ Process Writing } & \multicolumn{1}{c|}{ Product Writing } \\
\hline $\begin{array}{l}\text { Text as a resource for } \\
\text { comparison }\end{array}$ & Imitate model text \\
\hline Ideas as starting point & $\begin{array}{l}\text { Organization of ideas are } \\
\text { more important than ideas } \\
\text { themselves }\end{array}$ \\
\hline More than one draft & One draft \\
\hline $\begin{array}{l}\text { More global, focused on } \\
\text { purpose, theme, text type } \\
\text { i.e. reader is emphasized }\end{array}$ & $\begin{array}{l}\text { Features highlighted in- } \\
\text { cluding controlled practice } \\
\text { of those features }\end{array}$ \\
\hline Collaborative & Individual \\
\hline $\begin{array}{l}\text { Emphasis on creative pro- } \\
\text { cess }\end{array}$ & Emphasis on end product \\
\hline
\end{tabular}

Generally, the distinction can be summed up in this way: the process writing represents a shift in emphasis in teaching writing from the product of writing activities (the finished text) to ways in which text can be developed: from concern with questions such as 'what have you written?', 'what grade is it worth?' to 'how will you write it?', 'how can it be improved?'.

Although recently the respective boards of S.S.C or H.S.C have introduced the Communicative approach for teaching English, the English teachers are not properly trained in the new approach. The teachers are still more prone 
to practice the old Grammar Translation (GT) method. They are more guided by the controlled writing format, which hinders them in trying new approaches(s) to writing instruction. Teachers' feedback is based on grammatical and lexical errors instead of meaning-oriented exploration. In spite of the introduced new approach or sometimes on individual's choice of approach, the influence of alternative Western approaches to the teaching of writing, most of the Bangladeshi English teachers at college or university level still follow the product approach in the writing classes. The prominent influence of the product-based approach on over all teaching English can not be underestimated or negated fully.

Under the influence of product approach, the writing task is seen as decontextualized format; it ignores context and audience, and highlights the learner's final piece of work instead of how is produced, so the importance of process approach too needs to get underlined in this regard.

\section{Genre Approach}

Genre-based approach considers writing as a social and cultural practice. The purpose of this writing involves the context where the writing occurs, and the conventions of the target discourse community. In this sense, relevant genre knowledge needs to be taught explicitly in the language classroom. The genre approach to teaching writing, as Paltridge (2004) claims, emphasizes the teaching of particular genre students need for later social communicative success. The focus would be the language and discourse features of particular texts and the context in which the text is used. The notion of genre is defined as "abstract, socially recognized ways of using language' (Hyland, 2003, p.21) which are purposeful communicative activities employed by members of a particular discourse community (Swales, 1990). Genre approach emphasizes more on the reader, and on the conventions that a piece of writing needs to follow in order to be successfully accepted by its readership (Munice, 2002). The following table upholds a comparative study of genre and process approach:
Table 2: A comparison of genre and process orientations

(Hyland, 2003, p. 24)

\begin{tabular}{|l|l|l|}
\hline Attribute & Process & Genre \\
\hline Main Idea & $\begin{array}{l}\text { Writing is a think- } \\
\text { ing process } \\
\text { Concerned with the } \\
\text { act of writing }\end{array}$ & $\begin{array}{l}\text { Writing is a social } \\
\text { activity } \\
\text { Concerned with the } \\
\text { final product }\end{array}$ \\
\hline $\begin{array}{l}\text { Teaching } \\
\text { Focus }\end{array}$ & $\begin{array}{l}\text { Emphasis on cre- } \\
\text { ative writer }\end{array}$ & $\begin{array}{l}\text { Emphasis on reader } \\
\text { expectations and } \\
\text { product } \\
\text { How to produce } \\
\text { and link ideas } \\
\text { purposes effectively }\end{array}$ \\
\hline Advan- & $\begin{array}{l}\text { Makes processes } \\
\text { of writing trans- } \\
\text { parent } \\
\text { Provides basis for } \\
\text { teaching }\end{array}$ & $\begin{array}{l}\text { Makes textual con- } \\
\text { ventions transparent } \\
\text { Contextualizes writ- } \\
\text { ing for audience and } \\
\text { purpose }\end{array}$ \\
\hline $\begin{array}{l}\text { Disadvan- } \\
\text { tages }\end{array}$ & $\begin{array}{l}\text { Assumes Ll and L2 } \\
\text { writing similar } \\
\text { Overlooks L2 lan- } \\
\text { guage difficulties } \\
\text { Insufficient atten- } \\
\text { tion to product } \\
\text { Assumes all writing } \\
\text { uses same pro- } \\
\text { cesses }\end{array}$ & $\begin{array}{l}\text { Requires rhetorical } \\
\text { understanding of } \\
\text { texts } \\
\text { Can result in prescrip- } \\
\text { tive teaching of texts } \\
\text { Can lead to over } \\
\text { attention to written } \\
\text { products } \\
\text { Undervalue skills } \\
\text { needed to produce } \\
\text { texts }\end{array}$ \\
\hline
\end{tabular}

Genreinstruction has emerged as a set of pedagogies rooted in linguistic theory and a critical response to some of the tenets of whole language instruction (Hicks, 1997). According to Hyon (1996), current genre theories have developed in three research areas: English for Specific Purposes (ESP), North American New Rhetoric Studies, and Australian systematic functional linguistics.

In the context of Bangladesh, however, it is true that non-English major students know little about the actual process or conventions of genre-specific and its conventions (e.g. a job application letter, a résumé or an invitation) they are using in their writing, but they can produce them pretty well as they have learnt all those by rote.

There are some limitations that can be found in the genre approach. Paltridge (2001) mentions that genre approach combines both the knowledge of text as well as social, cultural for the students; as a result, specification of the either is a difficult job. It is also suggested by Swales (2000) that a genre approach over-focuses on the reader while paying less attention to learner expression. 


\section{Methodology}

The background of the students of our study can be divided into two ranks-one of them is intermediate, and the other one is lower intermediate. Their background also helps us to categorize as mixedability group. We took information and a writing test (a composition: An animal I kept as a pet) to check whether our participants (60 students) have successfully followed and learned the process we tried to impart to them. As English is increasingly becoming an integral part and more focused subject of private universities, we decided to take a composition test from United International University, Dhaka, Bangladesh. United International University is coming to fore as a reputed university among the leading private universities. My colleague and I are teaching English-II (which is named as Composition and Communication Skills) here; therefore, it is easier for us to implement both approaches and figure out whether one or the blend of the two is more applicable in our Bangladeshi context. We took data, that is, the writing test from 60 students of BBA. Out of them 40 students were male and the rest were female. We took the whole semester under our supervision to see their progress and we got the test as the culmination of our observation.

Under Product approach, we had 20 students as male and 10 as female, and also under Process approach, we had the same number of students for male and female. We also applied genre approach to both the classes. We took the background information of the students from our university's admission desk. We came across students from H.S.C/A Level/ Madrasa.

The English II course is based mainly on structure and classification of paragraph writing, different types of essay writing, and C.V. writing and job application letters. In a product approach, most of the time writing tasks encourage learners to imitate, copy and transform models provided by teachers or textbooks. When we as researchers followed product approach in the class, one of the classes was given and introduced a topic, for example, "Changes in the Family", from the course book "English Skills with Readings" by John Langan (2002), in order to write a paragraph, and the students were asked to familiarize themselves with the content of the topic of the book provided.
At the controlled stage, they were asked to produce some simple sentences about the topic given from the sample of the book. Then the learners produced a piece of guided writing based on the content, and, at the stage of free writing, they produced something closely related with the topic given, for example, a description of their own family and changes happening in recent years. After writing the composition, the students resubmitted it after feedback and corrections. When the students received the marked compositions, they corrected the errors by revising either the whole composition or those sentences that contained errors. This product approach employed here was done in the very beginning of the semester as they were, more or less, familiar with this teachercentered environment where the learners were not vocal like teachers. In the, aptly named, product approach, students' attention focuses on adhering to and duplicating models and in particular on correct language. Typically, students, in the class, adopted studying model texts and attempted various exercises aimed towards drawing attention to relevant features of a text.

The process approach is based on the recognition of the writing process as cyclical, recursive or even disorderly rather than simple or linear. The focus shifts from the text to the writer, and the writer/students in our case, jump back and forth from one stage to another when they write. The second chapter of the mentioned book (Fifth Edition) titled as "The Writing Process" gives the students a complete idea of process approach. The researchers asked the students of one of the English-II classes to go through the whole chapter to produce a write up based on given topic, "My Responsibilities Towards Others in My Home". In order to introduce and implement process approach in another class, the students were asked to get well-acquainted with (a) prewriting techniques, like (i) free writing, (ii) making a list (iii) clustering (iv) preparing a scratch outline (b) writing a first draft (c) revising and (d) editing. Students were also asked to select a topic that was of interest to them for writing a paragraph, and follow the process approach at home, and submit their respective topics as home task after two classes. Under the process approach, the students were encouraged to follow the core features of writing process, for example, stage1: in 
pre-writing students i) chose a topic, ii) gathered and organised ideas, iii) defined a topic sentence, stage 2: in drafting students i) wrote a rough draft, ii) emphasized content rather than mechanics, stage 3 : in revising students i) shared their writing with teacher or in writing groups, ii) participated constructively in discussions about classmates' writings, iii) made changes in their writings to reflect the reactions and comments of both teacher and classmates, iv) made substantive rather than only minor changes between the first and final drafts, stage 4: in editing students i) proofread their own or classmates' writing ii) increasingly identified and corrected their own mechanical errors, stage 5: in publishing students i) published their writing in appropriate form, ii) shared their finished writing with the teacher.

There are two mid-terms and a semester final examination in a semester for all of the students in the classes of English-II course. After two midterms, the students of both sections faced their semester final examination. The syllabus of their semester final examination consists of writing a job application, C.V. writing, essay writing, and a research paper writing. In both of the classes, following the genre approach, the students examined authentic descriptions of a C.V writeup, job application in order apply for a job now as a part timer or when they get their majors. They felt that they were to maintain the social context they were in for job application as well as résumé writing. Working on their own, they were asked to produce complete texts reflecting the social context and the language of the original description of job application or C.V. writing, which was corrected with due attention. In order to follow written and spoken genres, we asked students to write a set of procedures or instructions for accomplishing some tasks. First, we issued several sample sets of instructions (how to help students speak in English, to make a cup of tea, etc.) and had the class discuss them emphasizing their genre characteristics and structure, most notably their step-by-step sequential format, and stressing particularly the consequences of departing from the sequential format. We also can add that as researchers we identified three stages in genre approach to writing. First, we introduced and analysed a model of a particular genre. The students then were asked to carry out exercises which manipulated relevant language forms and, finally, produced a text. This paralleled product approach very closely. Besides, the incorporation of product-process approach in a classroom and its result has been discussed in the latter part of result and discussion.

\section{Results and Discussion}

Under the product approach, we found that the maximum number of students tried to recall their previous knowledge and some of them imitated model writing and some reproduced the original. This approach did not help them in producing a good composition given in the exam hall as they failed to showcase their ability to write effectively the structure of the composition in their answer scripts.

Under the process approach, we observed that most of the students faced problems in brainstorming and organizing their ideas cohesively as they were not familiar with the method. Our observation showed that later they could cope with it, but it took a long time to gather their ideas and organize them. We also noticed that some failed even after their several attempts as they could not extract the important points necessary for the topic. The researchers found that the students retreated back to their old fashioned paragraph writing without providing the structure of a paragraph, namely topic sentence, supporting details and a conclusion. The researchers took substantial time to correct them, and even it was found that at the end of the semester, some students did forget to write topic sentence of a paragraph, even gave two or three paragraphs when they were asked to write a paragraph in spite of much varying help from other sources.

As the students of our country are habituated to memorizing the content of any subject without understanding, they swallow all the materials and reproduce them in the examinations. Under the genre approach, our observation showed that after some months of their learning, if they encountered such a situation where they had to produce (as for example, an application letter) any of these genre-specific writings, they failed miserably to do that. On the basis of experiment of the process genre approach to teaching writing (Gao, 2007), 
we asked the students to do some practice on the features of target genres, but except to a few, they fell back to their old habit of getting by heart without understanding. This was a recurring aspect of selected non-major English classes, and this approach did not help them develop their creativity at all. When the researchers followed the genre approach in the classes, the students undervalued the skills needed to produce a text and saw themselves as largely passive. Under the genre approach, we were forced to impose our ideas on students by offering a models; substituting their own ideas for those students originally attempted to express. Clearly, this kind of feedback militates against student's need for autonomy and guidance in developing responsibility for editing, correcting, and proofreading their own papers. Even when we did interfere with students' editing or proofreading, we saw that they failed to come to terms with the correct form of the grammar, spelling or sentence-construction as they were originally weak writers, so they needed to get extra assistance from the teachers concerned, and also they did not authenticate their peers' judgment or checking or reviewing.

So, our firm belief from the experience of our teaching is that the contexts or conventions of the genre-based writing is not going to solve the problems of our students' writing as our main focus to Bangladeshi students is to make them independent writers; thus, they will be able to write the conventionalized writing based on genre approach with mere guidance from the teachers.

The reality-check observation shows that the students of our Private Universities are relatively poorer in English than those who get admitted to Public Universities. The paradox is here that those who are studying in Private Universities find that a lot of stress is put on learning all the four skills of English, namely speaking, writing, comprehending, and listening. Thus genre-based conventions and contextualized communicative activities do play a little role in their first year of graduation if we see the main aim set for the students is to help them write and speak effectively.

\section{Choice Between the Approaches}

Which approach is to be used will definitely depend on us, the teachers, on the students and on the genre of the text. For example, while teaching business report writing, we as well as the students felt comfortable in product approach as the task consists of the fixed layout, style and organization. On the contrary, in case of teaching narrative or argumentative essay, process approach proved to be our first choice. Thus, both process and product approaches are significant in teaching writing in EFL/ESL context. Process approach is really significant to let the students generate their ideas in a comprehensive manner. It helps a student to organize his/her thought in a systematic way which enables the student to write fluently in a different language which is not his/her mother tongue. On the other hand, the product approach is also important for a student to be able to realize the competence level he/she requires according to the task, age and maturity. So a collaborative approach, i.e. using both product and process approaches as per necessity, may be adapted by a teacher in an EFL/ESL classroom.

\section{Balancing Product and Process}

As there is the over-emphasis of grammar and final product in the Higher Secondary level in Bangladesh, students are provided with the texts which play a key role in their learning. In this traditional form-dominated approach, the students are confined within a supply of texts and can only produce or reproduce what they have as inputs from the sample texts. In fact, the evaluation of a writing is done on the usage of correct grammar, a range of vocabularies (specified in some cases), meaningful punctuation, accurate spelling (Hedge, 1988). Besides, for the concentration on the final product, students fail to realize that writing is a recursive process rather than a linear one. So when in the tertiary level, like in our case in a private university, they experience writing in a completely different context where they have to meet a wide range of genre and topics that require sufficient amount of critical thinking. Our study showed that the students were reluctant to learn the different approaches the researchers wanted to implement in the classes as they were more concerned about examinations and result; as a result, our students utterly failed to live up to the performance of our expectation.

Following (Batstone, 1994), to improve the situation 
we needed to mix 'the careful control of language for learner (as in product), and the creative use of language by the learner (as in process)' (Kim and Kim, 2005, pp.7-8). Scaffolding was a method for this (Kim \& Kim, 2005). This helps to create an active collaboration between a teacher and the learners and also between the learners themselves. The scaffolding is temporary as it is important for the successful construction of building, but it is a special kind of assistance that helps learners to move toward new skills, concepts or levels of understanding (Gibbons, 2002). During the early stages, direct instruction was crucial and we took a dominant role, ensuring that students were able to understand and produce or reproduce. In our case also this scaffolding method of writing has helped students acquire the knowledge and skills to be able to write their own texts with confidence.

In most cases, students of writing courses of our university come from different disciplines, such as Science, Business, Economics, etc. So, these courses might be incorporated with other subjectarea programme. In some cases (as in science) where the subject-content is very technical, it might prove difficult, but it is not completely impossible to explore the fields that could be merged with writing courses. In the Asian English for Specific Purposes (ESP) world, Bhatia (1993) and English for Business and Technology (EBT) specialists (Hyon, 1993) provide students with models, such as the sales promotion letter, business memo, job application, and lab report as well as a set of worksheets for identifying the language strategies in these genres and for constructing business and scientific texts using these strategies. Besides, we have incorporated product-process approach in a classroom in the following ways:

1) Guided Brainstorming has been adopted where we have supplied major ideas/points and asked the students to organize subpoints to support them in the brainstorming session on 'High Price of Product: Prevention and Solution'. When we supplied the main ideas as: 'Impact on a Society, Causes, and Prevention', the diagram, shown in figure 3, was done by one of the groups of students:

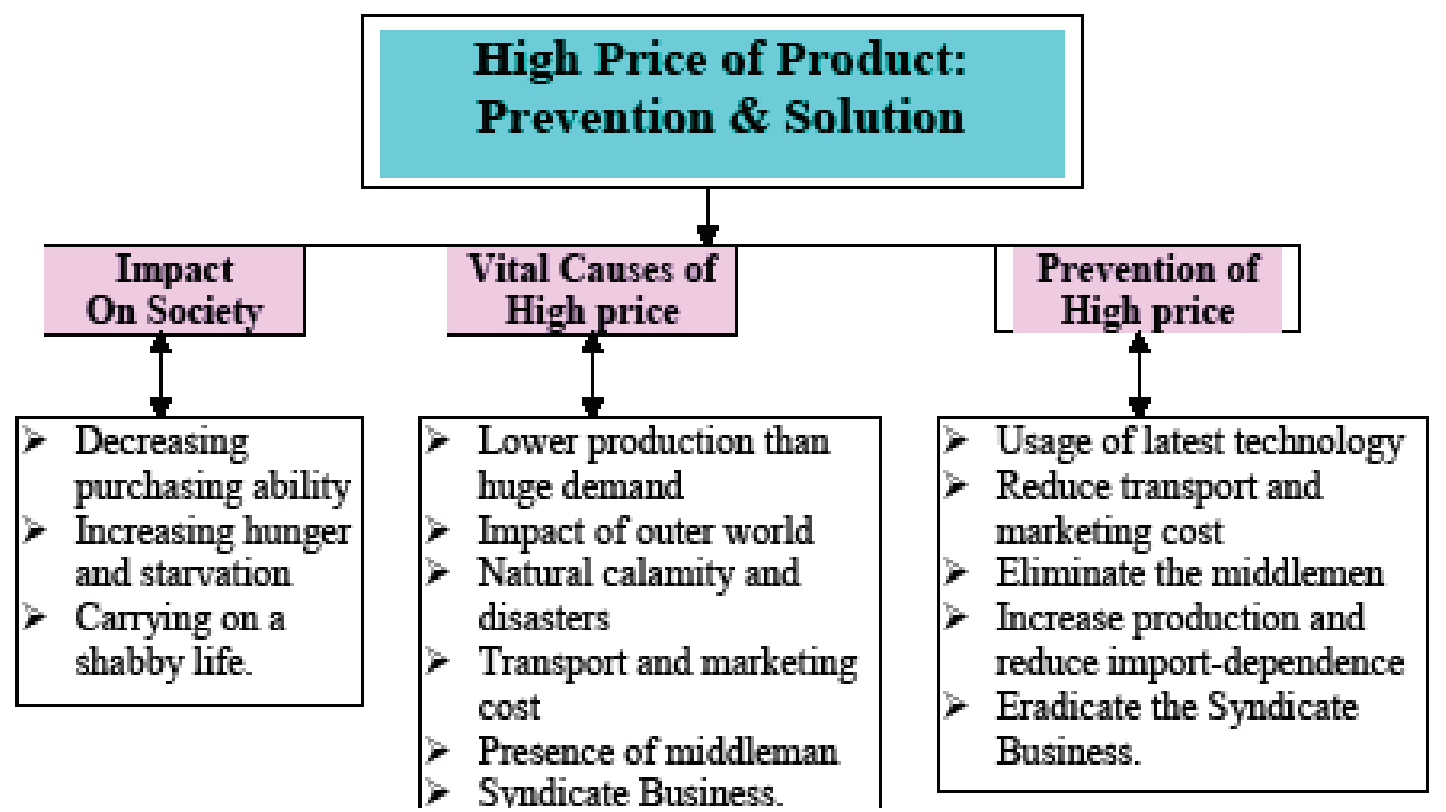

Figure 3: The Incorporation of Product- Process approach 
2) Top down approach in the organization of ideas has also been adopted in which we have given a text and asked the students to extract the important ideas/points on which it is written.

3) As the evaluation system of our country places heavy emphasis on the end product, familiar topic to write, but guiding them in different angle providing specific guided questions and/or points adopted by us has played a pivotal role in the class.

4) We also discussed some aspects of model text in the light of style, e.g. the use of certain language structure in a writing indicating level of formality, such as the use of "Sincerely Yours' and "Truly Yours" in our classes. This has made students realize that these are not to be imitated randomly, but to be used as per situation.

5) We have discussed in the classes the difference between an essay of level 10 and level 12 to clarify the importance of writer's and reader's identity.

\section{Conclusion}

In Bangladeshi writing classes, students have a variety of purposes for attending the class, such as obtaining good academic grades to obtain better jobs. So in EFL/ESL contexts like us, where English exposure is very instrumental, more fruitful approaches to teaching writing should be applied. To do this, neither the product, nor the process alone, nor the genre process approach by Gao (2007) is the best alternative for Bangladeshi students if we take the learning habit of our students into consideration. What we suggest is using the balanced instructional and curricular approach of the product and process approach to teaching writing. The emergence of genre theory does not attempt to replace or suggest abandoning the process approach to writing, but draws on the demand for a

more balanced approach to teaching ESL/ EFL writing (Kim \& Kim, 2005). Both product and process approaches have their benefits and drawbacks; accordingly, it is believed that complementary use of both approaches helps student writers develop their skills in using language by experiencing a whole writing process as well as gain knowledge from the model texts. Such a complementary use of both approaches would help students to be authors rather than copiers, and so have the potential benefit of integrating critical thinking into their academic writing.

Although the study that is presented here is local, and it is set in a specific institution of a specific country with its own norms and conventions, this study might be comprehensive for the countries that have similar issues in terms of the learning and teaching of writing, such as those that Kachru (1982; 1992)- indicates as countries belonging to the Expanding Circle, countries that recognize the importance of English as an international language and that teach English as a foreign/ second language. Moreover, Asian countries have many cultural, social and economic issues in common and so in many ways face similar issues in terms of English language teaching. In fact, here in this paper we have advocated the balanced approach to teaching or eclectic approach as the blending of process and product approach. By the help of this approach, we can say that the current English writing in Bangladeshi as well as in any Asian universities can be improved and proficiency in their writing can be enhanced.

Md. Kamrul Hasan is an assistant professor at the English Language Institute at United International University, Dhaka, Bangladesh. He has written six international conference papers, including papers presented in Nepal, Malaysia, Thailand, and Bangladesh. Out of his five published articles, one of his articles has been published in the Journal of Asia TEFL, Vol.7, No. 1, Spring 2010.

Mohd. Moniruzzaman Akhand is currently working as a lecturer in King Khalid University, KSA. He has been teaching English, Applied Linguistics and ELT for more than three years. He has presented papers in two international conferences.

\section{References}

Arndt, V. (1987). Six writers in search of texts: a protocol-based study of LI and L2 writing. ELT Journal, 41 (4), 257-67.

Badger, R. \& White, B. (2000). A process genre approach to teaching. ELT Journal, 54 (2),153160.

Batstone, R. (1994). Product and process: Grammar in the second language classroom. In Bygate, 
Martin, A. Tonkyn \& E. Williams (Eds.), Grammar and the language teacher. (pp.22436). New York: Prentice Hall.

Bhatia, V. (1993). Analyzing genre: language use in professional settings. Harlow, UK: Pearson Education.

Chen, Y.(2007). Learning to learn: the impact of strategy training. ELT Journal, 61 (1), 20-29.

Gabrielatos, C. (2002). EFL writing: product and process. Retrieved on 25 August. 2010 from $<$ http:// www.gabrielatos.com/Writing.pdf $>$

Originally published in three parts in ELT News 133, 134 \& 135 (March, April \& May 2000). The version used (February 2002) is available through ERIC. Cite as, ERIC, ED476839.

Gao, J. (2007). Teaching writing in Chinese universities: finding an eclectic approach. Asian EFL Journal (Teaching articles), 20 (2), 285-297.

Gardner, A., \& Johnson, D. (1997). Teaching personal experience narrative in the elementary and beyond. Flagstaff, AZ: Northern Arizona Writing Project Press.

Gibbons, P. (2002). Scaffolding language and scaffolding learning: teaching second language learners in the mainstream classroom. Portsmouth, NH: Heinemann.

Hedge, T. (1988). Writing. Oxford: Oxford University Press.

Hyland, K. (2003). Second language writing. Cambridge: Cambridge University Press.

Hyland, K. (2003). Genre-based pedagogies: A social response to process. Journal of Second Language Writing, 12, 17-29.

Hyon, S. (1996). Genre in three traditions: implications for ESL. TESOL Quarterly, 30 (4), 693-722.

Kachru, B.B. (1982). Models in non-native Englishes. In B.B. Kachru (Ed.), The other tongue: English across cultures (pp. 31-57). Urbana, IL: University of Illinois Press.

Kachru, B. B. (1992). Teaching world Englishes. In B. B. Kachru (Ed.), The other tongue. English across cultures (2nd ed, pp. 355-365). Urbana, IL: University of Illinois Press.

Kim, Y. \& Kim, J. (2005). Teaching Korean university writing class: balancing the process and the genre approach. Asian EFL Journal Online,
7 (2),69- 90. Retrieved on $25^{\text {th }}$ Jan. 2010 from http://www.asian-efl- journal.com/June_05_ yk\&jk.php

Kroll, B. (Ed.). (1990). Second language writing: research insights for the classroom. Cambridge: Cambridge University Press.

Langan, J. (2002). English skills with readings ( $5^{\text {th }} \mathrm{ed}$.). New York: McGraw-Hill.

Leki, I. (1990). Coaching from the margins: issues in written response. In B. Kroll (Ed.), Second language writing: research insights for the classroom (pp. 57 68). Cambridge: Cambridge University Press.

McCarthy, M. (1991). Discourse analysis for language teachers. Cambridge, UK: Cambridge University Press.

McDonough, J. \& Shaw, C. (1993). Materials and methods in ELT. Oxford: Blackwell Publishers.

Munice, J. (2002). Finding a place for grammar in EFL composition classes. EFL Journal, 56(2),180186.

Paltridge, B. (2001). Genre and the language learning classroom. Ann Arbor: University of Michigan Press.

Paltridge, B. (2004). Approaches to teaching second language writing. 17th Educational Conference Adelaide 2004. Retrieved on $20^{\text {th }}$ September 2010 from http://www. Englishaustralia.com.au/ea_conference04/ proceedings/pdf/Paltridge.pdf

Raimes, A. (1983). Techniques in teaching writing. Oxford: Oxford University Press.

Richards, J., Platt, J. \& Weber, H. (1985). Longman dictionary of applied linguistics. London: Longman.

Stanley, G. (2007). Approaches to process writing. Barcelona, Spain: British Council. Retrieved on 17th August 2010 from <http://www. teachingenglish.org.uk/think/write/process write.shtml>

Steele, V. (1992). Product and process writing: a comparison. Rowley: Newbury House.

Steele, V. (2004). Product and process writing. Retrieved on $5^{\text {th }}$ Sept. 2010 from http:// www.englishonline.org.cn/en/teachers/ workshops/teaching-writing/teaching-tips/ product-process 
Swales, J.M. (1990). Genre analysis: English in academic and research settings. Cambridge, MA: Cambridge University Press.

Swales, J. M. (2000). Further reflections on genre and ESL academic writing. Abstract of the keynote presentation to the Symposium on Second Language Writing, Purdue University, Lafayette, IN, September.

Trupe, A. L. (2001). Formative assessment of student writing. Retrieved on $24^{\text {th }}$ May 2009 from http://www.bridgewater.edu/WritingCenter/ Resources/sumform.htm

Ur, P. (1996). A course in language teaching. Cambridge, UK: Cambridge University Press.

Vygotsky, L. S. (1978). Mind in society: the development of higher psychological processes. Cambridge, MA: Cambridge University Press.
Wenden. A. (1987). Incorporating learner training in the classroom. In A. Wenden \& J. Rubin (Eds.), Learner strategies in language learning (pp. 159-68). Englewood Cliffs, NJ: Prentice Hall.

White, R. (1988). Academic writing: process and product”. In P. C. Robinson (Ed.), Academic writing: process and product. ELT documents 129. Modern English Publications and The British Council.

White, R. \& Arndt, V. (1991). Process writing. London: Longman.

Zamel, V. (1985). Responding to student writing. TESOL Quarterly, 19 (1), 79-101 